\title{
CORRECTION
}

\section{Correction to: Paediatric major trauma: demographics, management and outcomes at Cork University Hospital}

\author{
Liadan O'Sullivan ${ }^{1} \cdot$ Conor Deasy $^{1,2} \cdot$ Íomhar O'Sullivan $^{1}$
}

Published online: 18 November 2021

(c) The Author(s), under exclusive licence to Royal Academy of Medicine in Ireland 2021

Correction to: Irish Journal of Medical Science (2021) https://doi.org/10.1007/s11845-021-02848-0

The corresponding author would like to correct his affiliation from his home address to "Emergency Department, Cork University Hospital, Wilton, Cork, Ireland".

The original article has been corrected.

Publisher's Note Springer Nature remains neutral with regard to jurisdictional claims in published maps and institutional affiliations.

The original article can be found online at https://doi.org/10.1007/ s11845-021-02848-0.

Liadan O’Sullivan

Emergency Department, Cork University Hospital, Wilton, Cork, Ireland

2 School of Medicine, University College Cork, Brookfield Health Sciences Complex, Room 2.59 College Road, Cork, Ireland 